УДК 631.48

DOI https://doi.org/10.32848/agrar.innov.2021.10.11

\title{
РЕЗУЛЬТАТИ ОСТАННІХ ДОСЛІДЖЕНЬ ҐРУНТОВИХ ВІДМІН АНТАРКТИДИ. ОГЛЯД
}

\author{
ЛичУк Г.І. - кандидат сільськогосподарських наук, старший науковий співробітник \\ https://orcid.org/0000-0002-2579-5036 \\ Державна установа «Національний Антарктичний науковий центр \\ Міністерства освіти та науки України \\ TAPAPIКО Ю.О. - доктор сільськогосподарських наук, професор \\ https://orcid.org/0000-0001-8475-240X \\ Інститут водних проблем і меліорації Національної академії аграрних наук України
}

\begin{abstract}
Мета. Мета роботи - проаналізувати результати останніх досліджень ґрунтових середовищ Антарктиди, оцінити вагомість основних фракторів, що впливають на процеси ґрунтоутворення в різних її регіонах, встановити значення ґрунтів як індикаторів змін екологічних умов на континенті, запропонувати можливі напрями вдосконалення організації наукових досліджень антарктичних ґрунтових відмін.
\end{abstract}

Континентальні та субантарктичні регіони Антарктиди можна розмежувати на три біогеографічні зони: морську, субантарктичну і континентальну. Приморська Антарктида включає архіпелаги Арка Скотія, Південні Оркнейські, Південні Шетландські острови та більшу частину Антарктичного півострова на південь від острова Олександра. Субантарктичний регіон представлений різноманітними островами, розташованими недалеко від полярної фронтальної зони Антарктики. Континентальна Антарктида включає східні і південні райони Антарктичного півострова та решту території континенту [1]. У цих біогеографрічних регіонах знаходиться широкий спектр ґрунтів різного складу. Ці ґрунти $є$ переважно оліготрофннии і характеризуються вираженим стехіометричним дисбалансом [2]. Вони сформувалися у надзвичайно несприятливих умовах, за межею яких життя у будь якій формі взагалі неможливе. Тому антарктичні ґрунтові системи є дуже крихкими і вразливими до різних трансформацій навколишнього середовища. Цим зумовлена важливість проведення систематичних досліджень на типових для різних регіонів не вкритих льодом територіях. Моніторинг змін властивостей антарктичних ґрунтів дасть змогу моделювати наслідки змінних зовнішніх впливів, прогнозувати спрямованість процесів розвитку екологічної ситуації на континенті, опрацьовувати систему заходів на національному та міжнародному рівнях щодо збереження унікального природного середовища Антарктиди. Вважається, що основними факторами, що визначають трансформацію властивостей ґрунтів антарктичного континенту, є зміни клімату, прямий та опосередкований антропогенний вплив, а також тваринний світ [3, 4].

Те, що кліматичні зміни загалом впливають на цей континент, не викликає сумніву, оскільки численні результати досліджень клімату землі за тривалий період вказують на стрімке підвищення температури повітря у більшості прибережних регіонів Антарктиди, зокрема на території Антарктичного півострова [5]. Лише район моря Росса, що охоплює значну частину вільної від криги території, є єдиним регіоном, де не спостері- гається значного підвищення температури. На інших територіях потепління призводить до танення льоду, що супроводжується зволоженням до цього сухих ґрунтів. У свою чергу підвищена вологість змінює їх насиченість поживними речовинами, впливає на структуру ґрунтового мікробного ценозу та процеси трансформації вуглецю і азоту [6].

Масштаби антропогенного впливу вивчені у меншій мірі, але теж можуть супроводжуватися серйозними наслідками. Постійне зростання туристичної і дослідницької діяльності збільшує навантаження на доволі вразливі райони місцевої життєдіяльності [4]. Причому конкретні фрізичні дії людини є очевидними і легко вимірюються. Інші непрямі впливи потребують додаткових досліджень. Це можуть бути мікроорганізми і клітинний матеріал людини. Їх практично неможливо відстежувати без застосування суворого оперативного контролю. Водночас такі потенційні забруднювачі можуть і не зберігати життєздатність в найбільш жорстких умовах існування ґрунтового покриву, таких як у Сухих долинах в районі Мак-Мердо (77.405350, 161.597547). 3 іншого боку, з урахуванням холодних і сухих умов антарктичного ґрунтового середовища дія ксенобіотиків може бути дуже тривалою. Тобто практично нічого не відомо про наслідки таких непрямих хімічних і біологічних впливів, їх швидкості та віддаленої у часі стійкості, кількісних і якісних наслідків з погляду функціювання екосистеми.

Наприклад, природне середовище на острові КінгДжордж (62.001799, -58.327277) (Південні Шетландські острови) піддається значним порушенням з боку людини або шляхом простого витоптування, або через привнесення чужорідних видів і речовин. Це пов'язано з розташуванням на острові 9 дослідницьких станцій та його відвідування туристами. У результаті антарктичні морські птахи та ластоногі можуть вражатися неаборигенними мікроорганізми, оскільки останні добре виживають у відходах життєдіяльності людини. Деякі дослідження свідчать, що ґрунтові мікробні ценози також істотно змінюються під впливом людини $[7,8]$.

Вздовж берегової лінії Антарктики та прилеглих островів виділення тварин є ключовими елементами, що визначають поживний режим ґрунту та забезпечують його збагачення азотом, органічним вуглецем та іншими макро- та мікроелементами які підтримують життєдіяльність ґрунтової мікрофрлори [9]. Проведені на мисі Шерреффф (62.501130, -60.779279) на острові Лівінгстон (Південні Шетландскі острови) дослідження підтверджують гіпотезу про те, що склад угрупувань ґрунтових 
бактерій залежить від морських птахів і ластоногих. Це регіон, де діяльність людини суворо обмежується лише науковими дослідженнями [10]. Встановлено, що окремі види морських тварин мають свою власну мікробіоту шлунково-кишкового тракту, що і впливає на властивості ґрунтів [11].

На відміну від ссавців, що виділяють головним чином сечовину, у птахів відходами життєдіяльності $€$ в основному сечова кислота [12]. Основною здобиччю південних морських слонів $€$ головоногі молюски та риба, що за хімічними властивостями істотно відрізняє ґрунти, які фрормуються під їх впливом. У раціоні пінгвінів та антарктичних морських котиків переважає антарктичний криль. Тому за фізико-хімічними і біологічними властивостями виділяються ґрунти, що виникли в місцях тривалої локації колоній пінгвінів із великими покладами гуано. Поверхневий шар таких ґрунтів $є$ нейтральним, а більш глибокі шари виявилися слабокислими. Порівняно з іншими ґрунтовими середовищами кількість мінеральних елементів живлення, зокрема мінерального азоту і фоссрору, значно вища [13].

Однак велика кількість поживних речовин часто перешкоджає росту рослинності та знижує різноманітність бактеріальної спільноти. Це явище також може бути пов'язано з тим, що кріль містить багато фтору.

Крім того, високий вміст у цьому субстраті вуглецю і азоту, зокрема нітратів, у результаті потепління та активізації процесів мінералізації буде супроводжуватися інтенсифікацією викидів парникових газів $\left(\mathrm{CH}_{4}\right.$ і $\left.\mathrm{N}_{2} \mathrm{O}\right)$. Парниковий ефект від метану у 25 разів, а оксиду азоту у 300 разів сильніший порівняно з вуглекислим газом. Таке положення викликає занепокоєність, особливо коли надходять повідомлення про зростання популяцій деяких морських тварин [14].

На ґрунти Сухих долин також впливає тваринний світ континенту, зокрема у вигляді гуано і пір'я, морського детриту, що переноситься вітром, а також туш тюленів і пінгвінів, що за якихось причин потрапляють в цей район та помирають очевидно від голоду і знесилення. Муміфіковані туші тюленів відносно часто зустрічаються в Сухих долинах, що добре зберігаються в сухих та холодних умовах. Радіовуглецевий вік муміфікованих тюленів та пінгвінів за наявності рідкої води може коливатися до 2-3 століть. Поживні речовини розкладеної біомаси сприяють колонізації ґрунтової поверхні лишайниками.

Озера такожє точковими джерелами ресурсів у Сухих долинах. Накопичення в них відносно великої біомаси, зокрема внаслідок розвитку ціанобактерій, призводить до виникнення дисбалансу між виробництвом та споживанням. Продуктивність озер Сухих долин може коли-

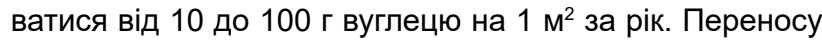
лише невеликої частини цієї кількості на поверхню землі може бути достатнім для підтримання наявних темпів дихання ґрунту. Про це опосередковано може свідчити підвищення виділення $\mathrm{CO}_{2} 3$ ґрунту 3 наближенням до озера та зниження концентрації органічного вуглецю із збільшенням глибини відбору. Механізм цього процесу полягає в накопиченні детриту на березі в результаті пов'язаних із погодою (замерзання джерел надходження талої води) коливань рівня озера. Осіла органічна речовина висихає та вітром перерозподіляється з вологих ділянок на навколишні більш сухі ґрунти.

Доступність поживних речовин істотно відрізняється у різних біогеографічних зонах. Ці відмінності у доступності елементів живлення відбиваються на фрілогенетичних та функціональних властивостях мікробних спільнот у ґрунтових середовищах різних біогеографічних регіонів або на особливостях розвитку рослинних організмів [15].

Дослідження ґрунтів антарктичної оази Пойнт-Томас $\left(62^{\circ} 10^{\prime} \mathrm{S} 58^{\circ} 30^{\prime} \mathrm{W}\right)$ (о. Кінг-Джордж, Південні Шетландські острови) були присвячені оцінці рівнів доступних для рослин поживних речовин. Встановлено, що кількість сполук, що визначалися, залежить від активності накопичення органічної речовини стосовно наявної сукцесії рослин, а на деяких ділянках - життєдіяльності морських птахів. Більша частина органічної біомаси накопичується в районі колонії пінгвінів. Усі досліджувані ґрунти виявилися багатими на доступні для рослин макро- і мікроелементи. Окрім переносу рибоїдними птахами біогенів, головним чином азоту і фоссрору, з моря на сушу, в подальшому також відбувається розсіювання вітром і поморниками біогенів по усій вільній від льоду території. Тобто поклади виділень морських тварин можна вважати резервуарами поживних речовин, у перспективі вони можуть бути використані іншими наземними організмами на вільних від криги територіях.

Один із пробілів, що став очевидним в процесі здійснення цього аналізу, полягає у тому, що дані про склад і кількість поживних речовин хоч і добре охоплюють ґрунтові середовища Антарктики, але $є$ дещо застарілими. Тому виникає питання, наскільки актуальні ці результати досліджень, оскільки кількість і доступність елементів живлення, зокрема азоту, могли змінитися за минулі роки [16, 17].

Сучасне відносно швидке потепління в деяких районах Антарктики, зокрема на Антарктичному півострові, наслідок підвищення доступності поживних речовин і води очевидно призведе до більш швидких змін у структурі та фрункціях ґрунтових мікробних ценозів. Тому 3 цього погляду обмежуючим фактором нашого розуміння закономірностей розвитку і взаємодії різних груп мікроорганізмів, їх реакції на поточні кліматичні перетворення $€$ наявність відповідних засобів вимірювання. Тобто потрібні більш масштабні і глибокі дослідні роботи, які полегшуються відносно простими трофічними структурами мікробних угрупувань та очікуваною достатньою для достовірного вимірювання їх стабільністю у часі.

Встановлення стратегій виживання різних видів мікробів має важливе значення для розуміння як екосистемних процесів, так і біогеохімічних зворотних зв'язків із кліматичними змінами [18]. Враховуючи стрімкий розвиток методологій і технологій, організація таких досліджень дасть змогу здійснювати прогнозування того моменту, коли властивості антарктичних ґрунтів стануть серйозною перешкодою для точної оцінки наявного мікробного різноманіття. У кінцевому рахунку це дасть змогу ефективно корегувати національну та міжнародну 
політику щодо діяльності на Антарктичному континенті та навколо нього.

Застосування метагеномного та метапротеомного підходів вже дозволило отримати цінну інформацію щодо біологічної функціональності морського середовища Антарктики. Такі підходи можуть також успішно широко і системно використовуватися і у наземних умовах [19, 20, 21].

Важливе значення мають дослідження функціональних маркерів $\mathrm{N}$-циклу в антарктичних ґрунтах стосовно основних генів, що беруть участь у процесах азотфріксації, нітрифікації та денітрифікації за допомогою метагеномних методів, секвенірування апліконів і технології мікрочіпів. Для оцінки активності азотфріксації мікробами антарктичних ґрунтів використовують ацетиленовий метод [22, 23].

Для Сухих долин Антарктики притаманні екстремальний холод, сухість, засоленість, низький рівень поживних речовин, високий рівень УФ-випромінювання, сильні стокові вітри. Однак, незважаючи на такі жорсткі умови, життя у цій місцевості все ж таки існує.

На півночі і півдні Землі Вікторії структура бактеріальної спільноти була визначена за допомогою методу молекулярного фрінгерпрінта 3 високою роздільною здатністю у 80 зразках ґрунту з долини Тейлор (77²37'S $163^{\circ} 00^{\prime}$ ) (частина Сухих долин Мак-Мердо) та мису Халлет (72.483492, 170.180708) (орнітогенні ґрунти). У результаті була встановлена висока просторова мінливість бактеріальних угрупувань, що корелювала з вологістю ґрунту та його кислотністю. Незважаючи на значну відстань між досліджуваними ділянками, були виявлені схожі як унікальні, так і відомі представники бактеріальної спільноти. У районі льодовика Маккей (77.050927, 161.327639) (Сухі долини Мак-Мердо) для вивчення структури мікробних угрупувань були відібрані 14 зразків ґрунтів. Ця територія класифікується як холодна гіперарідна пустеля з вічномерзлими мінеральними ґрунтами з низьким умістом органічної речовини $[24,25]$. У результаті досліджень встановлено високу неоднорідність антарктичних ґрунтів, що відбивалася на структурі мікробних ценозів головним чином за рахунок кислотності ґрунтового розчину. У ґрунтах із більш вологих ділянок чисельність ціанобактерій була більш високою. Штучне зволоження та додавання органічних речовин у ґрунти різної засоленості призвело до швидкої реакції бактеріальної спільноти, у якій переважаючі ацидобактерії та актинобактерії змінили протеобактерії. Ці спостереження вказують на те, що сформовані в умовах екстремального довкілля бактеріальні ценози $€$ дуже вразливими до зовнішніх впливів [26, 27].

Дослідження показали, що «кам'яні» мікробні ценози Сухих долин містять широкий спектр прокаріот та нижчих еукаріот з високим потенціалом накопичення біомаси. Це надзвичайно складні мікробні ценози, що включають значну кількість раніше невідомих мікробних організмів. Наявність таких мікробних угрупувань протирічить ствердженню про те, що мікробне різноманіття зворотно-пропорційне суворості кліматичних умов. Причому в дуже бідному поживними речовинами середовищі надходження фотоафтотрофного вуглецю має вирішальне значення для розвитку мікробної спільноти. Багато з ідентифрікованих фрілотипів $€$ азотфріксаторами та відповідають за відновлення дефріциту азоту в ґрунтах Сухої долини.

Нині оприлюднені результати комплексних досліджень вільних від льоду районів, до яких відносяться не тільки Сухі долини Мак-Мердо (77.405350, 161.597547), які у сукупності займають 15\% вільних від льоду площ на континенті, але й пагорби Вестфолд (68.612584, 78.148152) (Земля принцеси Єлизавети). Загалом встановлено, що в антарктичних ґрунтах переважають прокаріоти, хоча деякі еукаріоти (гриби, хлорофіти та мікрофрауна) також поширені. Мохоподібні та мікроводорості зустрічаються локально. В більшій частині едофічного середовища континентальної Антарктики кругообіг азоту переважно забезпечують прокаріоти [24, 25, 28].

Якщо озерні ціанобактерії та водорості $є$ джерелом надходження азоту у ґрунти Сухих долин Мак-Мердо, то на інших територіях надходження азоту визначається його кількістю в опадах $[25,27,29]$. Також існує думка про те, що азот субантарктичних ґрунтів на пагорбах вірогідно має рослинне походження. Дослідження, що проводилися у долині Маєрс, показали, що археї також приймають участь у фіксації азоту. Існує припущення, що ці таксони можуть бути домінуючими окислювачами аміаку в ґрунтових середовищах Сухих долин МакМердо. Як відомо, таумархеї є ключовими учасниками у глобальному кругообігу азоту в ролі нітрифрікаторів у широкому діапазоні місцеперебувань [30].

Багато грибів, включаючи дріжджі, продукують такі ферменти, як уреаза, та можуть відігравати важливу роль у мінералізації та амоніфікації азоту. Однак нині значення грибів і дріжджів в кругообігу азоту антарктичних ґрунтів все ще погано вивчене. Віруси також можуть відігравати дуже важливу роль у біогеохімічному кругообігу антарктичних ґрунтів, зокрема викликаючи диверсифікацію видів та зміну їх фрункціональності.

Отже, ґрунти Антарктики є єдиним середовищем мешкання значної кількості рослинних і тваринних організмів, регулюють кругообіг біогенних елементів та акумулюють органічну речовину і потребують подальшого детального вивчення. Загальне уявлення про особливості таких ґрунтів можна отримати на таких прикладах.

Оаза Ширмахера $(70.752867,11.647277)$ розташована вздовж узбережжя принцеси Астрід у 90 км на південь від моря Лазарєва. 3 Півночі оаза межує 3 шельфовим льодовиком Лазарєва, що відокремлює ії від моря. Це місцевість із пагорбами від 10 до 110 м загальною довжиною 18 км, шириною від 0,6 до 3,5 км. Клімат оази для Антарктики відносно м'який. Середньорічна температура становить $-10,3{ }^{\circ} \mathrm{C}$, температура найхолоднішого серпня становить $-17,9{ }^{\circ} \mathrm{C}$, найтеплішого січня $--0,4{ }^{\circ} \mathrm{C}$. Середньорічна кількість опадів становить 240 мм, у грудні та січні - 10 мм. Швидкість випаровування коливається від 350 до 590 мм на рік. Середньорічне значення відносної вологості становить 50\%. Завдяки властивостям підстилаючої поверхні температура повітря в оазі на протязі року вища порівняно з навколишніми льодовиками у середньому на $1-2{ }^{\circ} \mathrm{C}$. Типовий профріль ґрунту 
під мохом характеризується такою послідовністю горизонтів:

$\mathrm{O}_{i}$ - горизонт підстилки потужністю 1,5-2,5 см, складаються з живих та мертвих уламків моху, збагачених зернами мінерального піску;

$\mathrm{H}_{\mathrm{i}}$ - горизонт сухого торфу потужністю до $3 \mathrm{~cm}$, також багатий піщано-мінеральним матеріалом;

HВ - органо-мінеральний горизонт потужністю 3-5 см, піщаної текстури, містить живі та мертві ризоїди MOxy;

ВC - мінеральний горизонт з червонувато-коричневими плівками на окремих піщинках, підстилається вічною мерзлотою.

Загальна товщина ґрунтових профілів під мохом коливається віл 8 до 30 см.

Під лишайниками сукупність органічних горизонтів скорочується до поверхневого горизонту $\mathrm{O}_{i}$ у декілька міліметрів, що підстилається горизонтами НВ и ВС.

Наземна фрлора оази представлена 57 видами лишайників, 13 видами мохів та великою кількістю ґрунтових водоростей. За стійкості снігового покриву тривалість їх вегетаційного періоду може бути коротшою на тижні, сезони і навіть роки. Однак вони можуть збільшувати свою біомасу навіть під снігом, якщо останній товщиною не більше 30 см та створюється легкий парниковий ефект. Основним фактором посилення хімічного вивітрювання цими примітивними рослинами являється створення агресивних кислот. Встановлено також, що в цих умовах ціанобактерії у біоплівці на мінеральній поверхні знижують значення рН до 3-4, тоді як у інших випадках ці мікроорганізми підвищують $\mathrm{pH}$ до 9. Результати досліджень також показали, що органічний матеріал після цих рослин, незважаючи на окислювальне ґрунтове середовище, може зберігатися на протязі сотень років, що важливо для моделювання поточного балансу вуглецю у екосистемах антарктичних оаз. Це також може мати значення при реконструкції минулого вуглецевого циклу та кліматичних змін. Проведені дослідження підтверджують, що, незважаючи на слабкий розвиток цих ґрунтів, вони все таки накопичують свіжу органічну речовину. У холодному і сухому кліматі вона $є$ достатньо стабільною, однак буде легко розкладатися за потепління.

У районі пагорбів Ларсеманн $(69.400049,76.333610)$ у Східній Антарктиді (Земля принцеси Єлізавети) ділянки досліджень були розташовані як на майже природних, так і на антропогенно-забруднених територіях за присутності 4 дослідницьких станцій. Оаза Пагорби Ларсеманн $(69.400049,76.333610)$ глибоко розчленована короткими (до 1 км) долинами, які виникли вздовж лінеаментів у результаті льодовикової ерозії. Міжгірні долини - найважливіший структурний елемент оази, оскільки вони слугують ландшафтним фоном для фрормування вологих долин. Головна особливість клімату цієї оази - постійні сильні північно-східні вітри, що не стихають за більшу частину літа. У цю пору року долини заболочуються внаслідок танення льодовиків і мерзлого ґрунту, тому на ґрунтоутворення сильно впливають гідрологічні та кріогенні фрактори. Шар віч- ної мерзлоти залягає на глибині 95-100 см. Ця територія характеризується наявністю 56 видів лишайників, 7 видів мохів та біля 22 таксонів наземних водоростей. Таксономічний аналіз показав наявність 12 переважаючих типів бактерій та архірей. Деякі специфічні типи були також виявлені у підповерхневих горизонтах досліджуваних ґрунтів, що є додатковим доказом вирішальної ролі гравійного покриття у збереженні сприятливих умов як для ґрунту, так і для розвитку мікробіоми. Дослідження також показали, що деякі види бактерій можуть бути занесені в антарктичні ґрунти у результаті діяльності людини. Встановлено, що кислотність, уміст вуглецю і азоту, а також кількість дрібнозему $є$ найбільш точними предикторами бактеріального складу ґрунтової спільноти [31].

Висновки. Майже усі антарктичні ґрунти є оліготрофрними та мають дуже низький уміст органічного азоту та інших поживних речовин. Лише прибережні ґрунти, місця лежбищ пінгвінів та ластоногих надзвичайно багаті органічними сполуками і елементами живлення. Ïх запаси можуть також поповнюватися за рахунок морських аерозолів та відкладів морських водоростей.

Наявної кількості вимірювань і отриманих даних вкрай недостатньо, щоби змоделювати особливості кругообігу біогенних елементів в ґрунтових середовищах різних регіонів Антарктики. Адже точні результати вихідних вимірів вкрай важливі для майбутніх оцінок наслідків змін континентального клімату. Для вирішення цієї проблеми потрібно створити систему систематичного довгострокового моніторингу різних ґрунтових середовищ Антарктики з метою формування бази даних. Це, в свою чергу, дасть змогу встановити закономірності змін основних їх властивостей, зокрема складу, чисельності та активності мікробних угрупувань, динаміки вмісту різних форм поживних речовин та у цілому хімічного складу ґрунту.

Мікробні ценози Антарктики близькі до холодо-посушливої межі життя і є чутливими індикаторами порушень довкілля, зокрема кліматичних змін, особливо тих змін, що пов'язані з ключовими детермінантами виживання: доступністю води та літніми температурами (фотосинтетичними вікнами). Отже, комплексна оцінка їх структури та динаміки може слугувати ефективним інструментом моніторингу екологічного стану континенту. Згідно з кліматичними моделями, подальші зміни клімату можуть призвести до розширення вільних від льоду територій, що буде сприяти розвитку ґрунтів та трансформації ґрунтових спільнот. Основним фрактором, що обмежує ґрунтоутворення, є не температурний режим, а дефіцит вологи. Результати ґрунтових досліджень украй важливі для цілей оцінки екологічних ризиків та ефективного зберігання крихких антарктичних екосистем. Ґрунти морських зон Антарктиди можна розглядати як основний резервуар біогенів, що можуть вивільнятися у результаті кліматичних змін. Вплив антарктичних ґрунтів на загальний баланс вуглекислого газу незначний, а за можливого потепління його виділення збільшиться неістотно. 


\section{СПИСОК ВИКОРИСТАНОÏ ЛІТЕРАТУРИ}

1. Convey P. Antarctic ecosystems. In: Levin SA, editor. Encyclopedia of Biodiversity. 2nd ed. San Diego, CA, USA: 2013. pp. 179-188.

2. Cowan D.A. Microbiology of Antarctic Soils. Springer. Berlin/Heidelberg, Germany: 2014. 328 p.

3. Walther G. R., Eric Post E., Convey P., MenzelA., Parmesan C., Beebee T., Fromentin J., HoeghGuldberg O., Bairlein F. Ecological responses to recent climate change// Nature. 2002. V. 416. P. 389-395. doi: 10.1038/416389a

4. Walton D.W.H., Thomas J. Cruise Report-Antarctic Circumnavigation Expedition (ACE) 20th December 2016-19th March 2017. OpenAIRE

5. Dennis P.G., Newsham K.K., Rushton S.P., O'Donnell A.G., Hopkins D.W. Soil bacterial diversity is positively associated with air temperature in the maritime Antarctic. Sci. Rep. 2019 ; 9 : 2686. DOI: 10.1038 / s41598-019-39521-7.

6. Simmons B.L., Wall D.H., Adams B.J., Ayres E., et al. Long-term experimental warming reduces soil nematode populations in the McMurdo Dry Valleys, Antarctica. Soil Biol. and Biochem. 2009. 41, 2052-2060. DOI: 10.1016 / j.soilbio.2009.07.009

7. Pointing S.B., Chan Y., Lacap D.C., Lau MC.Y., Jurgens J.A., Farrell R.L. Highly specialized microbial diversity in hyper-arid polar desert. Proc. Natl. Acad. Sci. USA. 2009; 106 : 19964-19969. DOI: 10.1073 / pnas.0908274106.

8. De Scally S.Z., Makhalanyane T.P., Frossard A., Hogg I.D., Cowan D.A. Antarctic microbial communities are functionally redundant, adapted and resistant to short term temperature perturbations. Soil Biol. Biochem. 2016; 103: 160-170. DOI: 10.1016/ j.soilbio.2016.08.013.

9. Nylen T.H., Fountain A.G. Climatolotogy of katabatic winds in the McMurdo Dry Valleys, Antarctica. J.Geophs. Res. 2004; 109 :D03114. DOI: 10.1029/2003JD003937.

10. Han J., Jung J., Park M., Hyun S., Park W. Shortterm effect of elevated temperature on the abundance and diversity of bacterial and archaeal amoA genes in antarctic soils. J. Microbiol. Biotechnol. 2013; 23 : 1187-1196. DOI: 10.4014/ jmb.1305.05017.

11. Adriaenssens E.M., Kramer R., Van Goethem M.W., Makhalanyane T.P., Hogg I., Cowan D.A. Environmental drivers of viral community composition in Antarctic soils identified by viromics. Microbiome. 2017;5:83. doi: 10.1186/s40168-017-0301-7.

12. Falkowski P.G., Godfrey L.V. Electrons, life and the evolution of Earth's oxygen cycle. Philos. Trans. $R$. Soc. London / In Biol. Sci. 2008; 363 : 2705-2716. DOI: 10.1098 / rstb.2008.0054.

13. Ayton J., Aislabie J., Barker G.M., Saul D., Turner S. Crenarchaeota affiliated with group $1.1 \mathrm{~b}$ are prevalent in coastal mineral soils of the Ross Sea region of Antarctica. Environ. Microbiol. 2010;12:689-703. doi: 10.1111/j.1462-2920.2009.02111.x.

14. McCaig A.E., Phillips C.J., Stephen J.R., Kowalchuk G.A., Harvey S.M., Herbert R.A., Embley T.M., Prosser J.I. Nitrogen cycling and community structure of proteobacterial beta-subgroup ammonia-oxidizing bacteria within polluted marine fish farm sediments. Appl. Environ. Microbiol. 1999;65:213-220. doi: 10.1128/AEM.65.1.213-220.1999.
15. Bottos E.M., Laughlin D.C., Herbold C.W., Lee C.K., McDonald I.R., Cary S.C. Abiotic factors influence patterns of bacterial diversity and community composition in the Dry Valleys of Antarctica. FEMS Microbiol. Ecol. 2020;96:fiaa042. doi: 10.1093/femsec/ fiaa042.

16. Cain M.L., Subler S., Evans J.P., Fortin M.-J. Sampling spatial and temporal variation in soil nitrogen availability. Oecologia. 1999; 118 : 397-404. DOI: 10.1007 / s004420050741.

17. Knops J.M.H., Tilman D. Dynamics of soil nitrogen and carbon accumulation for 61 years after agricultural abandonment. Ecology. 2000; 81 : 88-98. DOI: 10.1890 / 0012-9658 (2000) 081.

18. Evans S.E., Wallenstein M.D. Climate change alters ecological strategies of soil bacteria. Ecol. Lett. 2014. 17, 155-164. DOI: 10.1111 / ele.12206.

19. Marco D., ed. (2011). Metagenomics: Current Innovations and Future Trends. Caister Academic Press. ISBN 978-1-904455-87-5.

20. DillB.D.,et al. "Metaproteomics: Techniques and Applications". Environmental Molecular Microbiology. Caister Academic Press. 2010. ISBN 978-1-904455-52-3.

21. Yau S., Lauro F.M., Williams T.J., DeMaere M.Z., et al. Metagenomic insights into strategies of carbon conservation and unusual sulfur biogeochemistry in a hypersaline Antarctic lake. The ISME. 2013. 7, 1944-1961. DOI:10.1038/ ismej.2013.69

22. Coyne K.J., Parker A.E., Lee C.K., Sohm J.A., KalmbachA., GundersonT.,León-ZayasR., CaponeD.G., Carpenter E.J., Cary S.C. The distribution and relative ecological roles of autotrophic and heterotrophic diazotrophs in the McMurdo Dry Valleys, Antarctica. FEMS Microbiol. Ecol. 2020; 96:fiaa010. doi: 10.1093/ femsec/fiaa010.

23. Asuming-Brempong S. Microarray Technology and Its Applicability in Soil Science - A Short Review. J. Soil Sci. 2012; 2 : 333-340. DOI: 10.4236/ ojss.2012.23039.

24. Lee C.K., Laughlin D.C., Bottos E.M., Caruso T., Joy K., Barrett J.E., Hopkins D.W., Pointing S.B., McDonal I.R., Cowan D.A., et al. Biotic interactions are an unexpected yet critical control on the complexity of an abiotically driven polar ecosystem. Commun. Biol. 2019;2:62. doi: 10.1038/s42003-018-0274-5.

25. Bottos E.M., Laughlin D.C., Herbold C.W., Lee C.K., McDonald I.R., Cary S.C. Abiotic factors influence patterns of bacterial diversity and community composition in the Dry Valleys of Antarctica. FEMS Microbiol. Ecol. 2020;96:fiaa042. doi: 10.1093/femsec/ fiaa042.

26. Bokhorst S., Convey P., Aerts R. Nitrogen inputs by marine vertebrates drive abundance and richness in Antarctic terrestrial ecosystems. Curr. Biol. 2019; 29 : 1721-1729. DOI: 10.1016 / j.cub.2019.04.038.

27. Winton V.H.L., Ming A., Caillon N., Hauge L., JonesA.E., Savarino J., Yang X., Frey M.M. Deposition, recycling and archival of nitrate stable isotopes between the air-snow interface: Comparison beteen Dronning Maud Land and Dome C, Antarctica. Atmos. Chem. Phys. 2020;20:5861-5885.doi: 10.5194/ acp-20-5861-2020.

28. Lepane V., Künnis-Beres K., Kaup E., Sharma B. Dissolved organic matter, nutrients, and bacteria in 
Antarctic soil core from Schirmacher Oasis. J. Soils and Sediments. Springer. 2018; 18:2715-2726. DOI: 10.1007 / s11368-018-1913-7.

29. Makhalanyane T.P., Valverde A., Velázquez D., GunnigleE., Van GoethemM.W., QuesadaA., CowanD.A. Ecology and biogeochemistry of cyanobacteria in soils, permafrost, aquatic and cryptic polar habitats. Biodivers. Conserv. 2015; 24 : 819-840. DOI: 10.1007 / s10531-015-0902-z.

30. Leininger S., Urich T., Schloter M., Schwark L., Qi J., Nicol G.W., Prosser J.I., Schuster S.C., Schleper C. Archaea predominate among ammonia-oxidizing prokaryotes in soils. Nature. 2006;442:806-809. doi: 10.1038/nature04983.

31. Nylen T.H., Fountain A.G. Climatolotogy of katabatic winds in the McMurdo Dry Valleys, Antarctica. J. Geophs. Res. 2004; 109 : D03114. DOI: 10.1029 / 2003JD003937.

\section{REFERENCES:}

1. Convey, P. (2013). Antarctic ecosystems. In S. A. Levin (Ed.). Encyclopedia of Biodiversity. (2nd ed.). San Diego, CA, USA.

2. Cowan, D. A. (2014). Microbiology of Antarctic Soils. Springer. Berlin/Heidelberg, Germany, 328.

3. Walther, G. R., Eric, Post E., Convey, P., Menzel, A., Parmesan, C., Beebee, T., Fromentin, J., Hoegh-Guldberg, O., Bairlein, F. (2002). Ecological responses to recent climate change. Nature, 416, 389-395. doi: 10.1038/416389a.

4. Walton, D. W. H., Thomas, J. (2017). Cruise Report - Antarctic Circumnavigation Expedition (ACE) 20th December 2016-19th March 2017. OpenAIRE;

5. Dennis, P.G., Newsham, K.K., Rushton, S.P., O'Donnell, A.G., Hopkins, D. W. (2019). Soil bacterial diversity is positively associated with air temperature in the maritime Antarctic. Sci. Rep., 9, 2686. DOI: 10.1038 / s41598-019-39521-7.

6. Simmons, B.L., Wall, D.H., Adams, B.J., Ayres, E., et al. (2009). Long-term experimental warming reduces soil nematode populations in the McMurdo Dry Valleys, Antarctica. Soil Biol. and Biochem., 41, 2052-2060. DOI:10.1016/ j.soilbio.2009.07.009

7. Pointing, S.B., Chan, Y., Lacap, D.C., Lau, MC. Y., Jurgens, J.A., Farrell, R.L. (2009). Highly specialized microbial diversity in hyper-arid polar desert. Proc. Natl. Acad. Sci. USA, 106, 19964-19969. DOI: 10.1073 / pnas.0908274106.

8. De Scally, S. Z., Makhalanyane, T. P., Frossard, A., Hogg, I. D., Cowan, D. A. (2016). Antarctic microbial communities are functionally redundant, adapted and resistant to short term temperature perturbations. Soil Biol. Biochem., 103, 160-170. DOI: 10.1016/ j.soilbio.2016.08.013.

9. Nylen, T.H., Fountain, A.G. (2004). Climatolotogy of katabatic winds in the McMurdo Dry Valleys, Antarctica. J.Geophs. Res., 109, D03114. DOI: 10.1029/ 2003JD003937.

10. Han, J., Jung, J., Park, M., Hyun, S., Park, W. (2013). Short-term effect of elevated temperature on the abundance and diversity of bacterial and archaeal amoA genes in antarctic soils. J. Microbiol. Biotechnol., 23, 1187-1196. DOI: 10.4014/ jmb.1305.05017.
11. Adriaenssens, E.M., Kramer, R., Van Goethem, M. W., Makhalanyane, T. P., Hogg, I., Cowan, D. A. (2017). Environmental drivers of viral community composition in Antarctic soils identified by viromics. Microbiome, 5(83). doi: 10.1186/s40168-017-0301-7.

12. Falkowski, P.G., Godfrey, L.V. (2008). Electrons, life and the evolution of Earth's oxygen cycle. Philos. Trans. R. Soc. London / In Biol. Sci. 363, 2705-2716. DOI: 10.1098 / rstb.2008.0054.

13. Ayton, J., Aislabie, J., Barker, G.M., Saul, D., Turner, S. (2010). Crenarchaeota affiliated with group $1.1 \mathrm{~b}$ are prevalent in coastal mineral soils of the Ross Sea region of Antarctica. Environ. Microbiol., 12, 689-703. doi: 10.1111/j.1462-2920.2009.02111.x.

14. McCaig,A.E.,Phillips, C.J.,Stephen, J.R., Kowalchuk, G.A., Harvey, S.M., Herbert, R.A., Embley, T.M., Prosser, J.I. (1999). Nitrogen cycling and community structure of proteobacterial beta-subgroup ammonia-oxidizing bacteria within polluted marine fish farm sediments. Appl. Environ. Microbiol., 65, 213-220. doi: 10.1128/ AEM.65.1.213-220.1999.

15. Bottos, E.M., Laughlin, D.C., Herbold, C.W., Lee, C.K., McDonald, I.R., Cary, S.C. (2020). Abiotic factors influence patterns of bacterial diversity and community composition in the Dry Valleys of Antarctica. FEMS Microbiol. Ecol., 96:fiaa042. doi: 10.1093/femsec/fiaa042.

16. Cain, M.L., Subler, S., Evans, J.P., Fortin, M.-J. (1999). Sampling spatial and temporal variation in soil nitrogen availability. Oecologia, 118, 397-404. DOI: 10.1007 / s004420050741.

17. Knops, J.M.H., Tilman D. (2000). Dynamics of soil nitrogen and carbon accumulation for 61 years after agricultural abandonment. Ecology, 81, 88-98. DOI: 10.1890 / 0012-9658 (2000) 081.

18. Evans, S.E., Wallenstein, M.D. (2014). Climate change alters ecological strategies of soil bacteria. Ecol. Lett., 17, 155-164. DOI: 10.1111 / ele. 12206.

19. Marco, D., ed. (2011). Metagenomics: Current Innovations and Future Trends. Caister Academic Press., ISBN 978-1-904455-87-5.

20. Dill, B.D., et al. (2010). "Metaproteomics: Techniques and Applications". Environmental Molecular Microbiology. Caister Academic Press, ISBN 978-1-904455-52-3.

21. Yau, S., Lauro, F.M., Williams, T.J., DeMaere, M. Z., et al. (2013). Metagenomic insights into strategies of carbon conservation and unusual sulfur biogeochemistry in a hypersaline Antarctic lake. The ISME, 7, 1944-1961. DOl:10.1038/ ismej.2013.69.

22. Coyne, K.J., Parker, A.E., Lee, C.K., Sohm, J.A., Kalmbach, A., Gunderson, T., León-Zayas, R., Capone, DG., Carpenter, E.J., Cary, S.C. (2020). The distribution and relative ecological roles of autotrophic and heterotrophic diazotrophs in the McMurdo Dry Valleys, Antarctica. FEMS Microbiol. Ecol., 96:fiaa010. doi: 10.1093/femsec/fiaa010.

23. Asuming-Brempong, S. (2012). Microarray Technology and Its Applicability in Soil Science - A Short Review. J. Soil Sci., 2, 333-340. DOI: 10.4236/ ojss.2012.23039.

24. Lee, C.K., Laughlin, D.C., Bottos, E.M., Caruso, T., Joy, K., Barrett, J.E., Hopkins, D.W., Pointing, S.B., McDonal, I.R., Cowan, D.A., et al. (2019). Biotic interactions are an unexpected yet critical control on the complexity of an abiotically driven polar ecosystem. Commun. Biol., 2, 62. doi: 10.1038/s42003-018-0274-5. 
25. Bottos, E.M., Laughlin, D.C., Herbold, C.W., Lee, C.K., McDonald, I. R., Cary, S. C. (2020). Abiotic factors influence patterns of bacterial diversity and community composition in the Dry Valleys of Antarctica. FEMS Microbiol. Ecol., 96:fiaa042. doi: 10.1093/femsec/fiaa042.

26. Bokhorst, S., Convey, P., Aerts, R. (2019). Nitrogen inputs by marine vertebrates drive abundance and richness in Antarctic terrestrial ecosystems. Curr. Biol., 29, 1721-1729. DOI: 10.1016 / j.cub.2019.04.038.

27. Winton, V.H.L., Ming, A., Caillon, N., Hauge, L. Jones, A. E., Savarino, J., Yang, X., Frey, M. M. (2020). Deposition, recycling and archival of nitrate stable isotopes between the air-snow interface: Comparison beteen Dronning Maud Land and Dome C, Antarctica. Atmos. Chem. Phys., 20, 5861-5885. doi: 10.5194/ acp-20-5861-2020.

28. Lepane, V., Künnis-Beres, K., Kaup, E., Sharma, B. (2018). Dissolved organic matter, nutrients, and bacteria in Antarctic soil core from Schirmacher Oasis. J. Soils and Sediments. Springer, 18, 2715-2726. DOI: 10.1007 / s11368-018-1913-7.

29. Makhalanyane, T.P., Valverde, A., Velázquez, D., Gunnigle, E., Van Goethem, M. W., Quesada, A., Cowan, D. A. (2015). Ecology and biogeochemistry of cyanobacteria in soils, permafrost, aquatic and cryptic polar habitats. Biodivers. Conserv., 24, 819-840. DOI: 10.1007 / s10531-015-0902-z.

30. Leininger, S., Urich, T., Schloter, M., Schwark, L., Qi, J., Nicol, G.,W., Prosser, J. I., Schuster, S. C., Schleper, C. (2006). Archaea predominate among ammonia-oxidizing prokaryotes in soils. Nature, 442, 806-809. doi: 10.1038/nature04983.

31. Nylen, T. H., Fountain, A. G. (2004). Climatolotogy of katabatic winds in the McMurdo Dry Valleys, Antarctica. J. Geophs. Res., 109, D03114. DOI: 10.1029 / 2003JD003937.

Личук Г.І., Тараріко Ю.О. Результати останніх досліджень ґрунтових відмін Антарктиди. Огляд

Майже на всіх ґрунтових картах світу Антарктида не представлена. Тим часом на цьому континенті $€$ не тільки ґрунти, а й навіть проявляються закони їх широтної зональності. Це означає, що ґрунти більш теплих узбереж дуже відрізняються від ґрунтів морозних внутрішніх районів. Щоправда, повноцінні ґрунти тут представлені лише як рідкісні дрібні вкраплення серед кам'янистих розсипів материка.

Ґрунтові середовища Антарктики різноманітні та займають в масштабі континенту мізерні площі. Їх унікальність надає величезні можливості для вивчення фундаментальних екологічних проблем. Ці середовища змінюються дуже повільно у тисячолітньому масштабі, у тій мірі, в якій на них впливають льодовикові умови континенту. Однак останніми десятиліттями на антарктичне довкілля посилився вплив потепління клімату, антропогенних чинників та тваринного світу. Таке положення у першу чергу відбивається на не вкритих льодом територіях, зокрема на ґрунтових відмінах стосовно особливостей окремих антарктичних біогеографрічних зон. Використання сучасних методів досліджень дає змогу ефективно вивчати різні властивості окремих ґрунтових середовищ, що дає змогу простежувати спрямованість їх еволюції у часі. Для розуміння рушійних сил розвитку різних мікробних угрупувань потрібно здійснювати систематичну кількісну оцінку хімічного складу ґрунтів та особливостей змін відповідних біохімічних циклів. Такий моніторинг у свою чергу дасть змогу будувати прогнозні моделі розвитку екологічної ситуації в різних регіонах континенту під дією зовнішніх змінних фракторів. Адже за наявності фрагментарних та неповних результатів досліджень низки антарктичних ґрунтів аналітикам не вистачає кількісних оцінок, потрібних для обґрунтування таких прогнозів.

Ключові слова: Антарктика, ґрунтові середовища, фрактори впливу, поживний режим, мікробний ценоз, хімічні властивості, екологічний стан, прогноз.

Lychuk A.I., Tarariko Yu.O. Results of recent studies of soil varieties in Antarctica. A review

Antarctica is not represented on almost all soil maps of the world. Meanwhile, on this continent there are not only soils, but even serve the laws of their latitudinal zonation. This means that the soils of warm coasts are very different from the soils of frosty inland areas. However, high-grade soils are represented here only by rare small areas among the stony placers of the mainland.

Antarctic soil substrates are diverse and occupy scanty areas across the continent. Their uniqueness provides great opportunities to study fundamental environmental problems. These environments change very slowly over millennia, to the extent that the continent's glacial conditions affect them. However, the effects of global warming, anthropogenic factors and wildlife have increased in recent decades on the Antarctic environment. This situation is primarily reflected in the areas not covered by ice, in particular on soil differences in the characteristics of certain Antarctic biogeographical zones. The use of modern research methods makes it possible to effectively study the various properties of individual soil environments, which allows us to trace the direction of their evolution over time. To understand the driving forces of the development of different microbial groups, it is necessary to carry out a systematic quantitative assessment of the chemical composition of soils and the peculiarities of changes in the relevant biochemical cycles. Such monitoring, in turn, will allow to build forecast models of ecological situation development in different regions of the continent under the influence of external variables factors. After all, in the presence of fragmentary and incomplete research results of a number of Antarctic soils, analysts do not have enough quantitative estimates needed to substantiate such predictions.

Key words: Antarctica, soil substrates, factors of influence, nutritional regime, microbial cenosis, chemical properties, ecological condition, forecast. 